\title{
Perancangan Sistem Informasi Kependudukan di Lingkungan Rukun Tetangga atau Rukun Warga Berbasis Web
}

\author{
Dede Kurniadi $^{1}$, Yosep Septiana ${ }^{2}$, Asri Rahayu Ningsih ${ }^{3}$, Heri Suhendar ${ }^{4}$ \\ Jurnal Algoritma \\ Institut Teknologi Garut \\ Jl. Mayor Syamsu No. 1 Jayaraga Garut 44151 Indonesia \\ Email : jurnal@itg.ac.id \\ 1dede.kurniadi@itg.ac.id \\ 2yosep.septiana@itg.ac.id \\ 31706025@itg.ac.id \\ 4herysuhendar@itg.ac.id
}

\begin{abstract}
Abstrak - Selama ini sistem informasi kependudukan seringkali diterapkan di tingkat pemerintah Desa untuk membantu dalam proses pencatatan kependudukan. RT/ RW merupakan ujung tombak pemerintah dalam pencatatan kependudukan. Sebagaimana hal tersebut perlu ditunjang teknologi yang bisa membantu kinerja RT/ RW dalam proses pendataan penduduk. Pendataan penduduk yang dilakukan RT/ RW di Desa Kota Kulon seringkali terjadi kesalahan data akibat human error dan menghasilkan data yang kurang akurat serta sering terjadi pengulangan pekerjaan pada saat data penduduk dibutuhkan. Hal ini terjadi disebabkan karena proses pengelolaan dan pengarsipan data penduduk masih dilakukan secara manual. Berdasarkan permasalahan tersebut maka tujuan penelitian ini adalah merancang sistem informasi kependudukan di lingkungan RT/ RW menggunakana bahasa pemograman PHP, dengan database MySQL dan metodologi yang digunakan yaitu Rational Unified Process (RUP) yang tahapannya terdiri dari inception, elaboration, dan contruction. Kemudian menggunakan pemodelan Unified ModellingLanguage(UML). Penelitian ini menghasilkan sistem informasi kependudukan di lingkungan RT/ RW yang bisa digunakan untuk mengelola data kependudukan serta membantu penduduk dalam mengajukan surat pengantar.
\end{abstract}

Kata Kunci - Pelayanan Kependudukan; RT/RW; Rational Unified Process.

\section{PENDAHULUAN}

Seiring dengan terus berkembangnya teknologi sangat mempengaruhi seluruh aspek kegiatan. Tujuan kehadiran teknologi informasi adalah untuk mempermudah pengerahan sumber daya penyembaran informasi dan mengkoordinasi aktivitas masyarakat [1]. Salah satu manfaat kemajuan teknologi informasi yaitu dapat membantu mengoptimalkan pelayanan terhadap masyarakat [2]. Sehingga pada saat ini berbagai proses pengolah data perlu menyesuaikan dengan perkembangan teknologi, maka penerapan sistem informasi dalam bidang administrasi kependudukan merupakan salah satunya [3]. Administrasi kependudukan merupakan kegiatan yang dilakukan untuk menata dan menerbitkan dokumen serta data kependudukan, melalui pendaftaran penduduk, pencatatan sipil, dan informasi administrasi kependudukan yang telah dikelola yang hasilnya digunakan untuk pelayanan publik [4]. RT/ RW mempunyai peran yang penting dalam nilai-nilai budaya serta kesatuan masyarakat untuk membangun kehidupan yang sejahtera [5]. Salah satu fungsi Rukun Tetangga (RT)/ Rukun Warga (RW) sebagaimana dalam Peraturan Menteri Dalam Negeri No. 5 Pasal 15 tahun 2007 tentang Penataan Lembaga Kemasyarakatan yaitu pada poin (a) pendatan kependudukan dan pelayanan administrasi pemerintahan lainnya. Berdasarkan hal tersebut RT/ RW ikut membantu dalam proses administrasian kependudukan [6]. Di lingkungan RT/ RW pada Desa Kota Kulon Kecamatan Garut Kota 
Kabupaten Garut, proses pendataan penduduk dilakukan sesuai prosedur yang berjalan dengan cara konvensional, masih menggunakan buku agenda serta arsip-arsip yang tersimpan dalam bentuk hardcopy.

Sistem administrasi kependudukan pada dasarnya bagian dari administrasi negara, yang berperan penting untuk mengelola data kependudukan. RT/ RW, Kelurahan dan Kecamatan merupakan ujung tombak dalam pelaksanaan pendataan penduduk yang bertanggung jawab kepada Pemerintahan Kabupaten/ Kota [7]. Pemerintah telah banyak mengembangkan sistem informasi kependudukan untuk meningkatkan pelayanan terhadap masyarakat menggunakan media teknologi informasi [8]. Di Desa Kota Kulon Pendataan penduduk yang dilakukan RT/ RW seringkali terjadi kesalahan data akibat human error dan menghasilkan data yang kurang akurat. Hal ini terjadi disebabkan karena proses pengelolaan data penduduk masih dilakukan secara manual. Selain itu pada waktu perpindahan jabatan RT /RW, data seringkali hilang karena arsip tidak tertata dengan baik.

Pada penelitian sebelumnya, yang pertama sistem kependudukan hanya membahas mencakup data pindah datang dan pindah keluar serta pelaporan data pindah datang dan keluar. Sistem kependudukan ini diterapkan di tingkat kelurahan [9]. Penelitian yang kedua membahas mengenai pembuatan surat pengantar kartu keluarga dan KTP sementara untuk mempermudah kantor kelurahan dalam proses pembuatan surat pengantar dan kartu keluarga. Sistem ini diterapkan di kantor kelurahan [10]. Penelitian yang ketiga, pada hasil penelitian aplikasi yang dibuat masih berbasis desktop dan hanya bisa diakses pada satu komputer saja dengan hak akses oleh KASI Pemerintahan [4]. Penelitian yang keempat, pada hasil penelitian aplikasi yang dibuat diharapkan dapat membantu mempermudah pendataan penduduk dan pelaporan [11]. Pada penelitian kelima aplikasi yang dibangun diharapkan dapat meningkatkan kinerja staff desa dalam pengelolaan data kependudukan. Sistem yang dirancang hanya untuk menfasilitasi perangkat desa [12]. Berdasarkan hasil tinjauan penelitian sebelumnya belum membahas mengenai pembuatan surat pengantar, klasifikasi penduduk berdasarkan kelompok usia, jenis kelamin, agama dan jenjang pendidikan, maka tujuan penelitian ini merancang sistem informasi kependudukan di lingkungan RT/ RW dimana pelayanan yang akan dilakukan melalui sistem ini berfokus pada pendataan RT /RW, warga, pengelolaan data Kartu Keluarga (KK), Kartu Tanda Penduduk (KTP) serta pengelompokan penduduk berdasarkan kelompok usia, jenis kelamin, agama dan jenjang pendidikan.

\section{METODOLOGI PENELITIAN}

Metodologi yang digunakan adalah Rational Unified Process (RUP). RUP adalah proses rekayasa perangkat lunak yang dikembangkan oleh Rational Software dengan pendekatan iterative dan menggunakan Unified Modelling Language (UML) untuk pemodelan [13]. Kerangka kerja \& Work Breakdown Structure pada penelitian ini ada pada Gambar 1. 


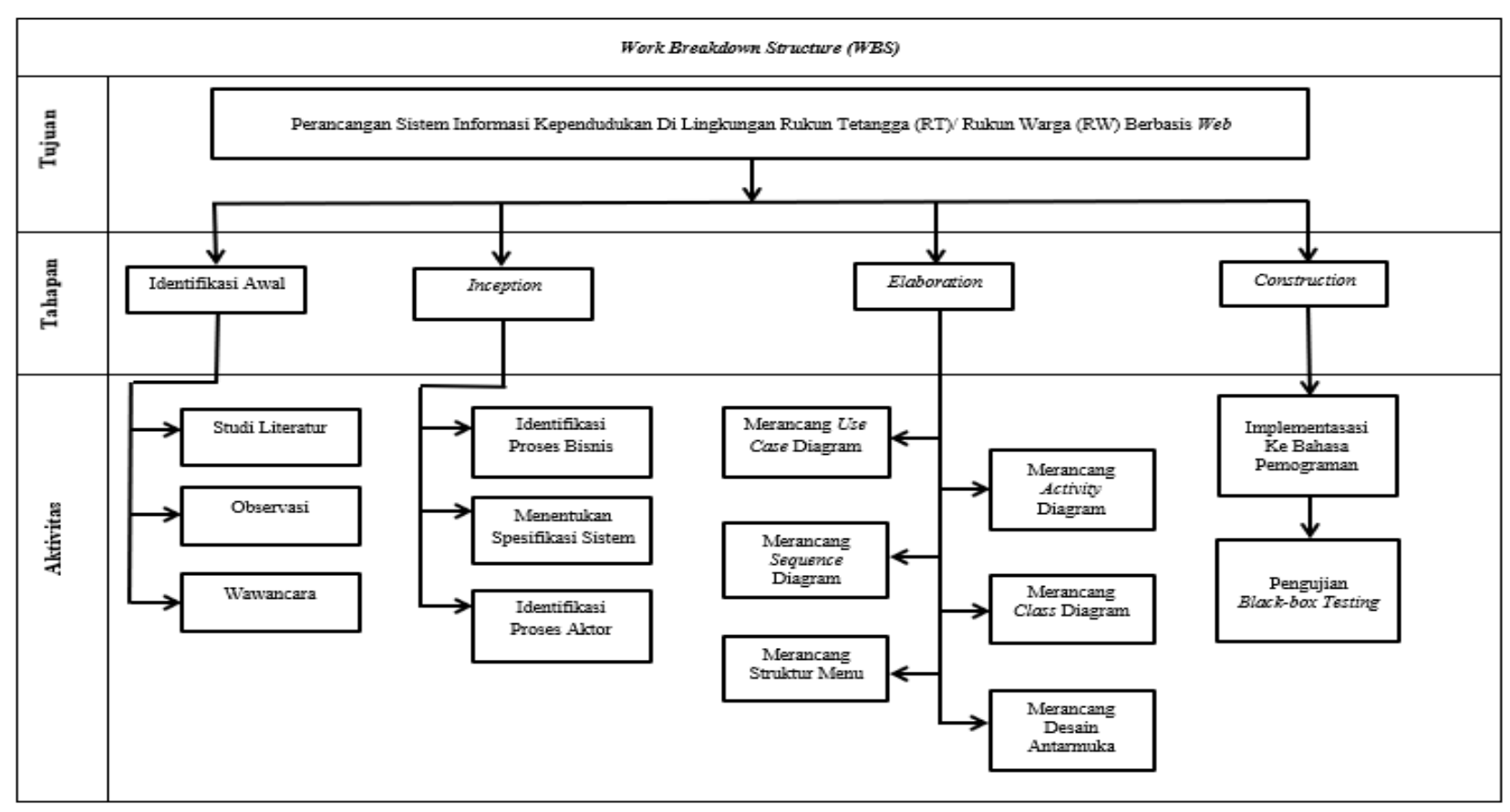

Gambar 1: Work Breakdown Structure (WBS)

Berikut merupakan deskripsi dari WBS sebagai berikut:

1. Identifikasi Awal

Identifikasi awal adalah tahap pengumpulan data dengan cara melakukan wawancara terhadapap pihak terkait objek penelitian dan studi literatur dengan mengumpulkan data-data terkait penelitian melalui analisis objek, buku, jurnal dan titeratul penunjang lainnya. Adapun hasil dari identifikasi awal berupa rumusan masalah untuk diidentifikasi pada tahapan inception.

2. Inception

Tahap inception merupakan tahapan untuk menganalisis data kebutuhan sistem sehingga menghasilkan proses bisnis, spesifikasi sistem, serta aktor yang menggunakan sistem.

3. Elaboration

Pada tahapan ini kemudian akan digambarkan use case diagram dan activity diagram serta merancang sequence diagram, class diagram, struktur menu, dan interface.

4. Contruction

Pada tahapan construction ini dilakukan implentasi ke dalam bahasa pemograman sistem sehingga menghasilkan sistem informasi dan diuji menggunakan metode black box testing dengan hasil akhir aplikasi versi alpha.

\section{A. Hasil Penelitian}

\section{HASIL DAN PEMBAHASAN}

Hasil dari penelitian ini adalah sistem informasi kependudukan di lingkungan RT/ RW berbasis web yang dapat digunakan oleh admin, penduduk dan RT/ RW yang ada di Kelurahan Kota Kulon untuk mengajukan surat pengantar kepada RT/RW, mengelola data penduduk, serta pelaporan. Berikut merupakan hasil aktivitas sesuai dengan tahapan metodologi Rational Unified Process (RUP). Adapun Bahasa pemograma yang digunakan yaitu PHP dengan framework Laravel.

\section{Identifikasi Awal}

Dalam tahapan ini merupakan tahapan analisis kebutuhan dengan menentukan dan membatasi kebutuhan dari sistem yang akan dibuat serta membatasi kebutuhan dari stakeholder yang terlibat pada sistem[14]. 
Dalam tahapan ini kebutuhan sistem dan proses bisnis didapatkan setelah melakukan studi literatur pada buku, jurnal dan literatur penunjang lainnya. Teknik selanjutnya yang digunakan untuk melakukan analisa adalah dengan cara observasi langsung untuk mengamati prosedur dan proses pendataan penduduk yang dilakukan RT/ RW 13 Desa Kota Kulon, Kecamatan Garut Kota, Kabupaten Garut, serta melakukan wawancara dengan narasumber RT/ RW setempat [15].

\section{Inception}

Pada tahap inception, setelah melakukan wawancara dan studi literatur selanjutnya mengidentifikasi proses bisnis yang sedang berjalan serta membuat spesifikasi sistem dan identifikasi aktor dari sistem yang akan dibuat.
a. Identifikasi Proses Bisnis
Tahapan ini dilakukan wawancara dan studi literatur untuk pengumpulan kebutuhan yang mengahasilkan sebuah proses bisnis.
b. Membuat Spesifikasi Sistem
Pada tahapan ini dideskripsikan kebutuhan apa saja yang dibutuhkan dalam perancangan aplikasi, kebutuhan ini meliputi persyaratan tampilan serta persyaratan sistem serta persyaratan perancangan.
c. Identifikasi Aktor
Setelah melakukan identifikasi terhadap sistem informasi yang akan dibuat menghasikan empat aktor yang akan terlibat pada sistem informasi kependudukan yang akan dirancang yaitu Admin, Penduduk, RT dan RW.

\section{Elaboration}

Pada tahap ini dilakukan rancangan arsitektur sistem dengan menggambarkan use case diagram, activity diagram, sequence diagram, class diagram, struktur menu, dan interface.

a. Perancangan Use Case Diagram

Perancangan use case dilakukan untuk mengetahui fungsi apa saja yang ada dalam sistem yang akan dirancang serta mengetahui hak akses dari fungsi sistem tersebut. Sistem informasi ini terdapat empat user yaitu admin dengan hak akses dapat mengelola laporan dan mengelola user RW, RT dapat mengelola penduduk, mengelola user penduduk, mengelola data KK, dan mengelola surat pengantar, RW dapat mengelola laporan dan mengelola user RT, serta penduduk dapat mengajukan surat pengantar, mengisi data KTP dan KK. Berikut merupakan rancangan use case diagram dapat dilihat pada Gambar 2.

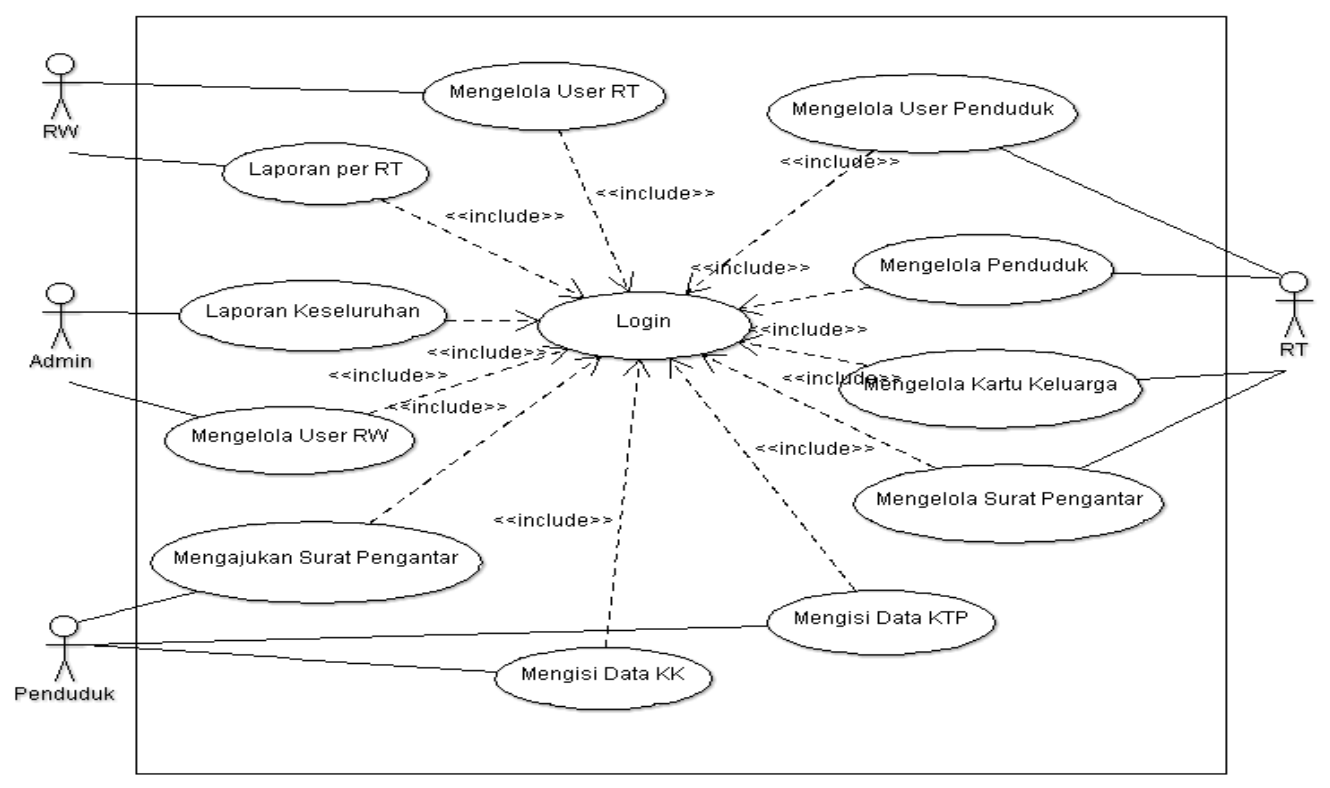

Gambar 2: Use Case Diagram 
b. Perancangan Activity Diagram

Penggambaran activity diagram digunakan untuk mendeskripsikan apa saja yang bisa dilakukan oleh oleh sistem. Berikut merupakan activity diagram perancangan sistem informasi kependudukan di lingkungan RT/ RW terlihat pada Gambar 3.

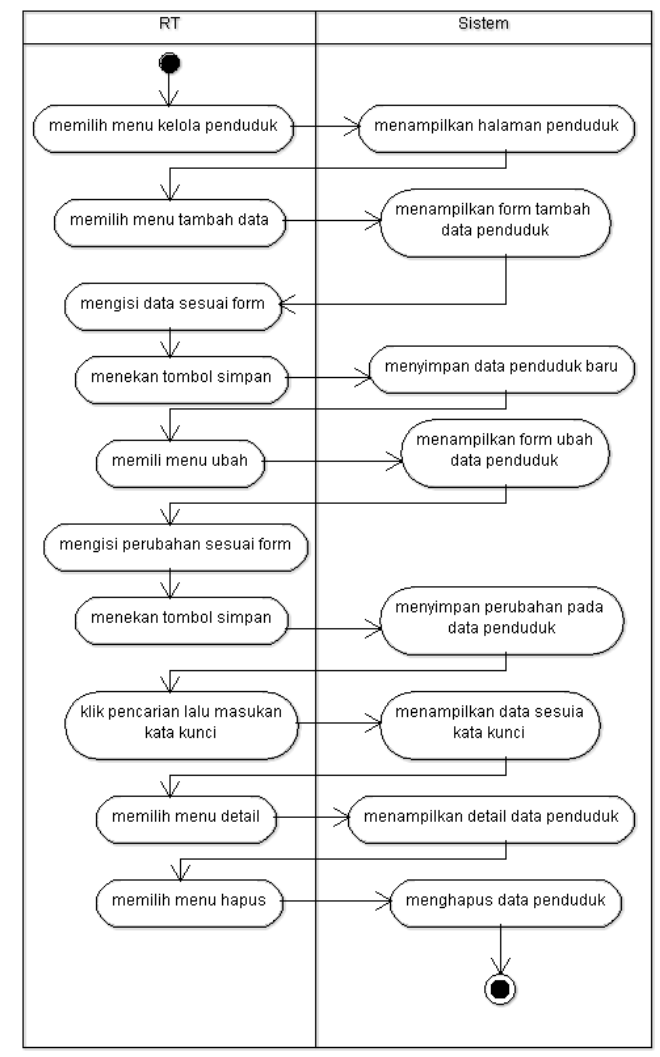

Gambar 3: Activity Diagram Mengelola Data Penduduk

c. Perancangan Sequence Diagram

Interaksi antara aktor dengan sistem digambarkan melalui sequence diagram. Berikut merupakan sequence diagram perancangan sistem informasi kependudukan di lingkungan RT/ RW dapat dilihat pada Gambar 4. 


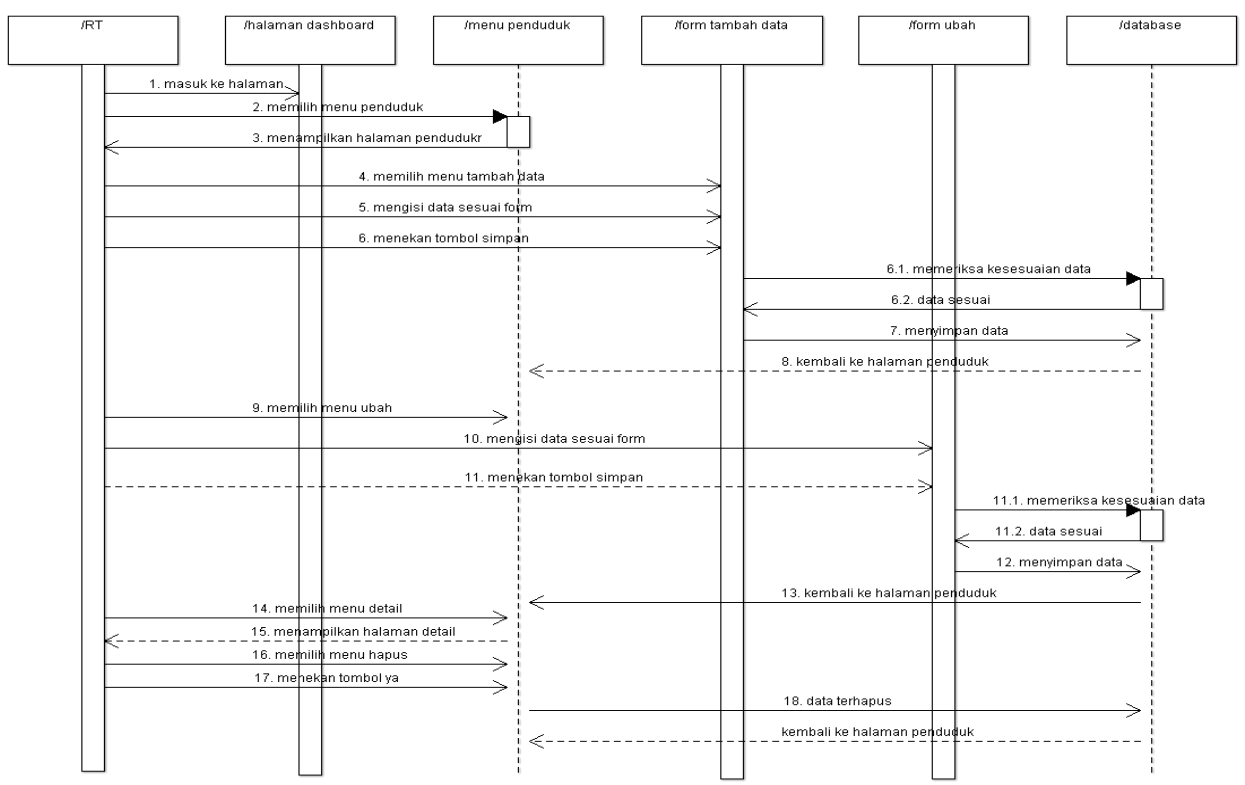

Gambar 4: Sequence Diagram Mengelola Data Penduduk

\section{d. Perancangan Class Diagram}

Class Diagram_adalah salah satu diagram yang digunakan untuk pengembangan berorientasi objek (OOP) yang merupakan kumpulan dari beberapa Class dan relasinya. Berikut merupakan class diagram perancangan sistem informasi kependudukan di lingkungan R/RW dapat dilihat pada Gambar 5.

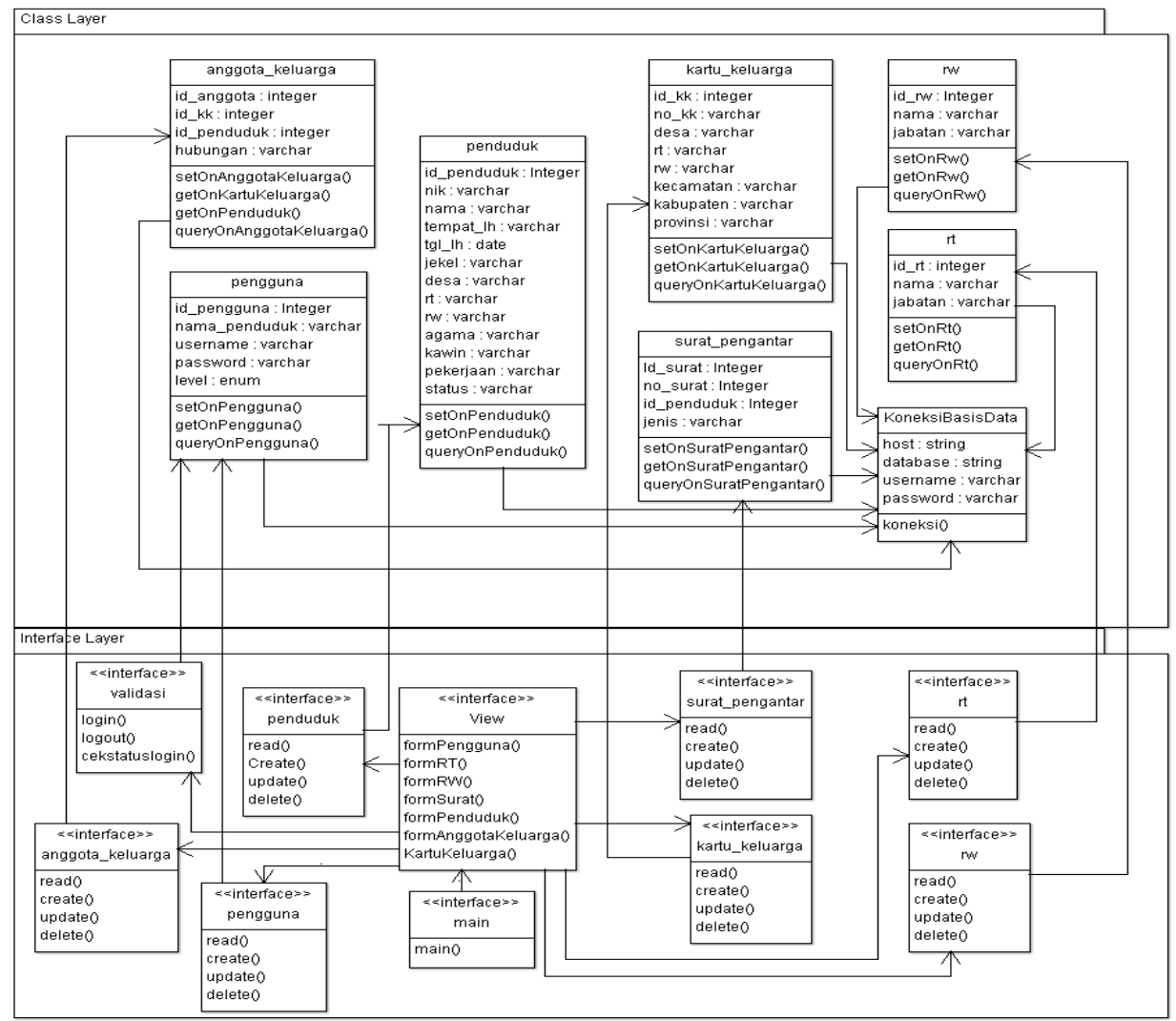

Gambar 5: Class Diagram Perancangan Sistem Informasi Kependudukan 
e. Perancangan Struktur Menu

Struktur menu digambarkan untuk mendeskripsikan rincian sistem yang akan dibuat. Berikut merupakan struktur menu sistem informasi kependudukan di lingkungan RT/ RW dapat dilihat pada Gambar 6.

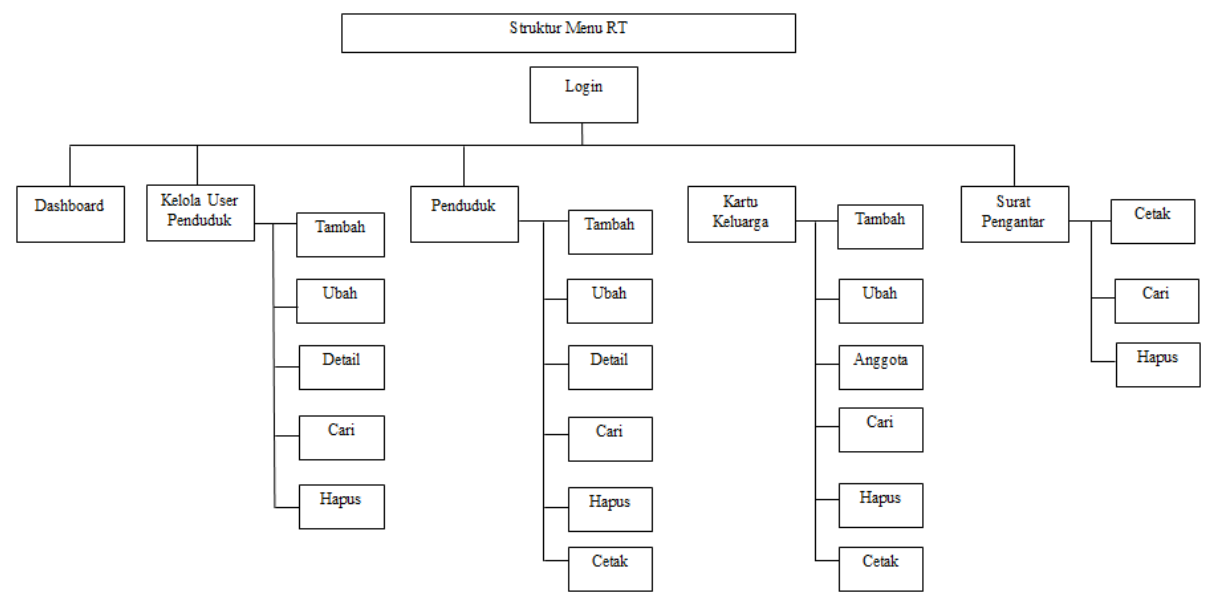

Gambar 6: Struktur Menu Perancangan Sistem Informasi Kependudukan

f. Perancangan Interface

Perancangan interface dibuat untuk merancang gambaran sementara dari sistem yang akan dibuat. Berikut merupakan interface perancangan sistem informasi kependudukan di lingkungan RT/ RW dapat dilihat pada Gambar 7.

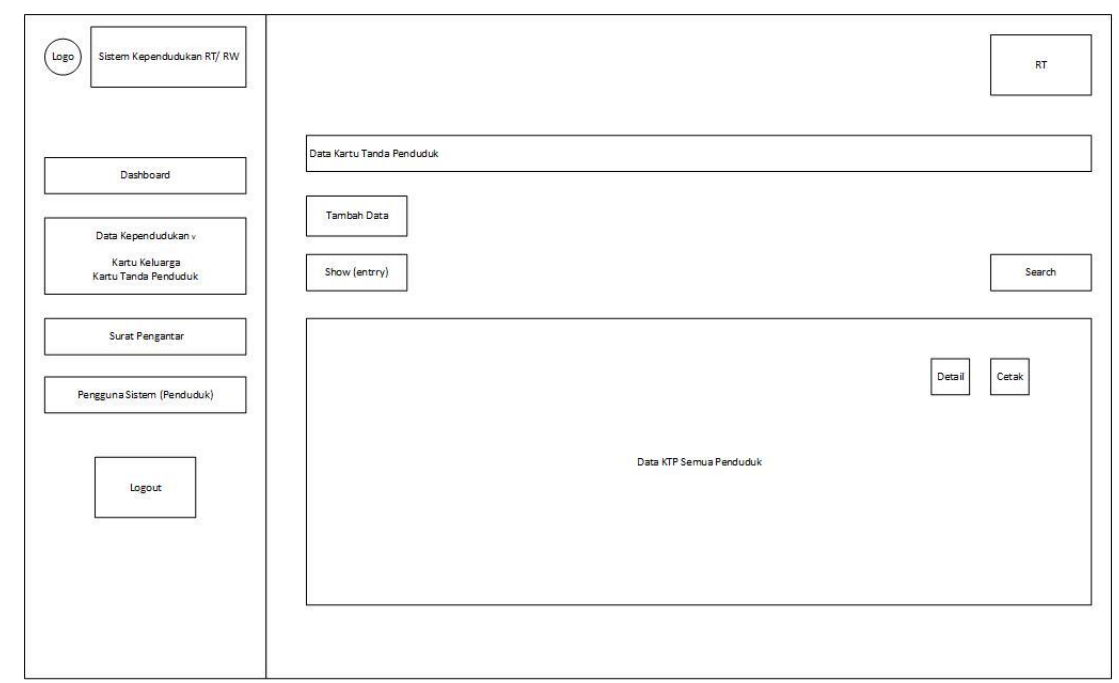

Gambar 7: Interface Perancangan Sistem Informasi Kependudukan

\section{Construction}

Pada tahapan construction ini, perancangan yang telah dibuat sebelumnya kemudia diimplementasikan ke dalam bahasa pemograman. Berikut merupakan hasil dari implementasinya:

a. Implementasi Program

Pembuatan sistem kependudukan di lingkungan RT/ RW ini dibuat dengan menggunakan bahasa pemograman PHP. Berikut merupakan hasil implentasi dari perancangan sebelumnya: 


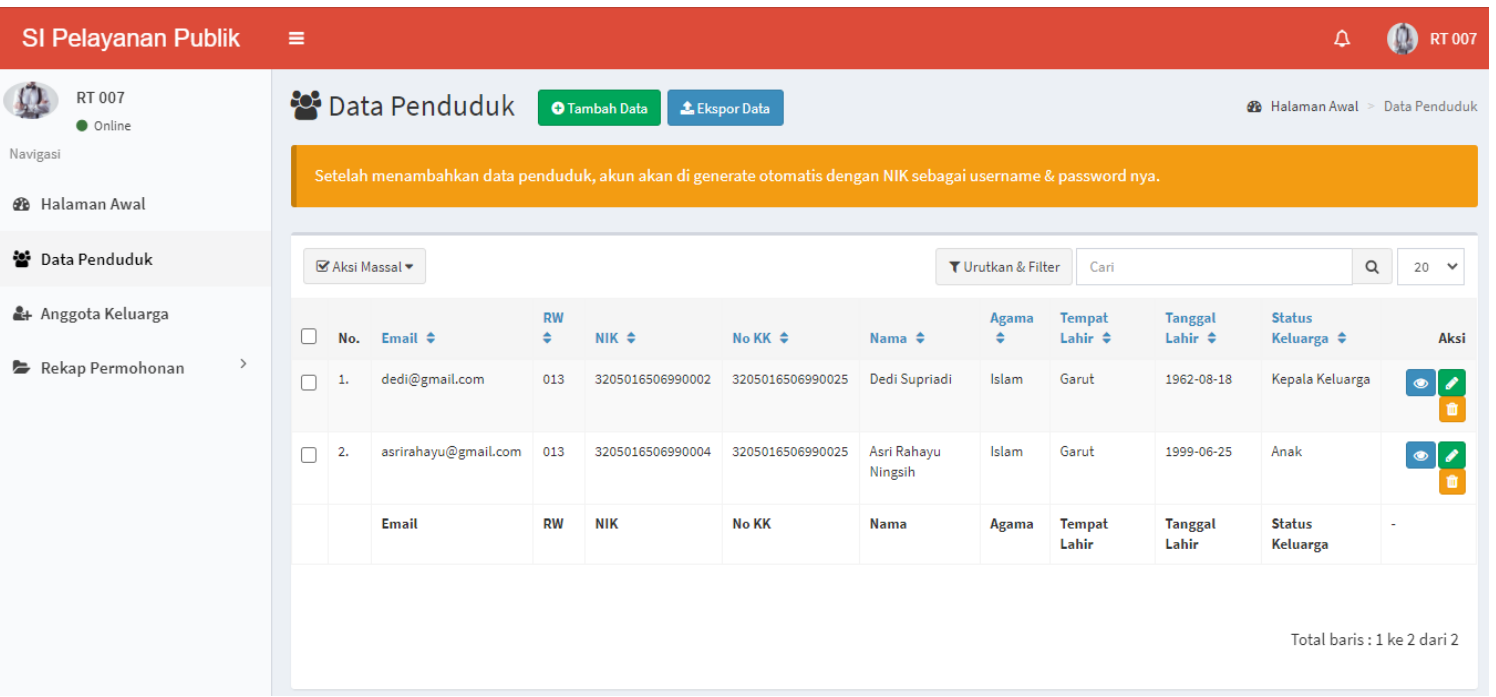

Gambar 8: Implentasi Perancangan Sistem Informasi Kependudukan

b. Pengujian

Pengujian ini dilakukan menggunakan teknik blackbox testing versi alpha untuk mengetahui apakah sistem sudah berjalan dengan semestinya.

Tabel 1: Hasil Pengujian

\begin{tabular}{|c|c|c|c|c|}
\hline Aktor & Aktivitas & Kelas Uji & Hasil yang diharapkan & Kesimpulan \\
\hline $\begin{array}{l}\text { Admin, RT, RW } \\
\text { \& Penduduk }\end{array}$ & Login & Login & $\begin{array}{l}\text { Mengakses system dengan } \\
\text { menggunakan username } \\
\text { \& password }\end{array}$ & Sesuai \\
\hline \multirow[t]{8}{*}{ Admin } & \multirow[t]{5}{*}{$\begin{array}{l}\text { Mengelola } \\
\text { Data User }\end{array}$} & $\begin{array}{l}\text { Melihat data } \\
\text { user }\end{array}$ & Dapat melihat data $u s e r$ & Sesuai \\
\hline & & $\begin{array}{l}\text { Menambah } \\
\text { data } \text { user }\end{array}$ & $\begin{array}{l}\text { Dapat menambahkan data } \\
\text { user }\end{array}$ & Sesuai \\
\hline & & $\begin{array}{l}\text { Mengubah } \\
\text { data user }\end{array}$ & Dapat mengubah data user & Sesuai \\
\hline & & $\begin{array}{l}\text { Menghapus } \\
\text { data } \text { user }\end{array}$ & $\begin{array}{l}\text { Dapat menghapus data } \\
\text { user yang dipilih }\end{array}$ & Sesuai \\
\hline & & $\begin{array}{l}\text { Mencari data } \\
\text { user }\end{array}$ & $\begin{array}{l}\text { Dapat menampilkan data } \\
\text { user yang dicari }\end{array}$ & Sesuai \\
\hline & \multirow[t]{3}{*}{ Laporan } & $\begin{array}{l}\text { Melihat } \\
\text { laporan }\end{array}$ & Dapat melihat laporan & Sesuai \\
\hline & & $\begin{array}{l}\text { Mengunduh } \\
\text { laporan }\end{array}$ & Dapat mengunduh laporan & Sesuai \\
\hline & & $\begin{array}{l}\text { Mencetak } \\
\text { laporan }\end{array}$ & Dapat mencetak laporan & Sesuai \\
\hline \multirow[t]{5}{*}{ RW } & \multirow{5}{*}{$\begin{array}{l}\text { Mengelola } \\
\text { Data User } \\
\text { RT }\end{array}$} & Melihat data & Dapat melihat data user & Sesuai \\
\hline & & user RT & RT & \\
\hline & & $\begin{array}{l}\text { Menambah } \\
\text { data user RT }\end{array}$ & $\begin{array}{l}\text { Dapat menambahkan data } \\
\text { user RT }\end{array}$ & Sesuai \\
\hline & & $\begin{array}{l}\text { Mengubah } \\
\text { data user RT }\end{array}$ & $\begin{array}{l}\text { Dapat mengubah data user } \\
\text { RT }\end{array}$ & Sesuai \\
\hline & & $\begin{array}{l}\text { Menghapus } \\
\text { data user RT }\end{array}$ & $\begin{array}{l}\text { Dapat menghapus data } \\
\text { user yang dipilih }\end{array}$ & Sesuai \\
\hline
\end{tabular}




\begin{tabular}{|c|c|c|c|c|}
\hline Aktor & Aktivitas & Kelas Uji & Hasil yang diharapkan & Kesimpulan \\
\hline & & $\begin{array}{l}\text { Mencari data } \\
\text { user RT }\end{array}$ & $\begin{array}{l}\text { Dapat menampilkan data } \\
\text { user yang dicari }\end{array}$ & Sesuai \\
\hline & Laporan & $\begin{array}{l}\text { Melihat } \\
\text { laporan }\end{array}$ & Dapat melihat laporan & Sesuai \\
\hline & & $\begin{array}{l}\text { Mengunduh } \\
\text { laporan }\end{array}$ & Dapat mengunduh laporan & Sesuai \\
\hline & & $\begin{array}{l}\text { Mencetak } \\
\text { laporan }\end{array}$ & Dapat mencetak laporan & Sesuai \\
\hline \multirow[t]{17}{*}{ RT } & $\begin{array}{l}\text { Mengelola } \\
\text { User }\end{array}$ & $\begin{array}{l}\text { Melihat data } \\
\text { user } \text { Penduduk }\end{array}$ & $\begin{array}{l}\text { Dapat melihat data user } \\
\text { Penduduk }\end{array}$ & Sesuai \\
\hline & Penduduk & $\begin{array}{l}\text { Menambah } \\
\text { data user } \\
\text { Penduduk }\end{array}$ & $\begin{array}{l}\text { Dapat menambahkan data } \\
\text { user Penduduk }\end{array}$ & Sesuai \\
\hline & & $\begin{array}{l}\text { Mengubah } \\
\text { data user } \\
\text { Penduduk }\end{array}$ & $\begin{array}{l}\text { Dapat mengubah data } \text { user } \\
\text { Penduduk }\end{array}$ & Sesuai \\
\hline & & $\begin{array}{l}\text { Menghapus } \\
\text { data user } \\
\text { Penduduk }\end{array}$ & $\begin{array}{l}\text { Dapat menghapus data } \\
\text { user yang dipilih }\end{array}$ & Sesuai \\
\hline & & $\begin{array}{l}\text { Mencari data } \\
\text { user Penduduk }\end{array}$ & $\begin{array}{l}\text { Dapat menampilkan data } \\
\text { user yang dicari }\end{array}$ & Sesuai \\
\hline & $\begin{array}{l}\text { Mengelola } \\
\text { Penduduk }\end{array}$ & $\begin{array}{l}\text { Melihat data } \\
\text { Penduduk }\end{array}$ & $\begin{array}{l}\text { Dapat melihat data } \\
\text { Penduduk }\end{array}$ & Sesuai \\
\hline & & $\begin{array}{l}\text { Menambah } \\
\text { data Penduduk }\end{array}$ & $\begin{array}{l}\text { Dapat menambahkan data } \\
\text { Penduduk }\end{array}$ & Sesuai \\
\hline & & $\begin{array}{l}\text { Mengubah } \\
\text { data Penduduk }\end{array}$ & $\begin{array}{l}\text { Dapat mengubah data } \\
\text { Penduduk }\end{array}$ & Sesuai \\
\hline & & $\begin{array}{l}\text { Menghapus } \\
\text { data Penduduk }\end{array}$ & $\begin{array}{l}\text { Dapat menghapus data } \\
\text { penduduk yang dipilih }\end{array}$ & Sesuai \\
\hline & & $\begin{array}{l}\text { Mencari data } \\
\text { Penduduk }\end{array}$ & $\begin{array}{l}\text { Dapat menampilkan data } \\
\text { penduduk yang dicari }\end{array}$ & Sesuai \\
\hline & $\begin{array}{l}\text { Mengelola } \\
\text { Kartu } \\
\text { Keluarga }\end{array}$ & $\begin{array}{l}\text { Melihat data } \\
\text { Kartu } \\
\text { Keluarga }\end{array}$ & $\begin{array}{l}\text { Dapat melihat data Kartu } \\
\text { Keluarga }\end{array}$ & Sesuai \\
\hline & & $\begin{array}{l}\text { Menambah } \\
\text { data Kartu } \\
\text { Keluarga }\end{array}$ & $\begin{array}{l}\text { Dapat menambahkan data } \\
\text { Kartu Keluarga }\end{array}$ & Sesuai \\
\hline & & $\begin{array}{l}\text { Mengubah } \\
\text { data Kartu } \\
\text { Keluarga }\end{array}$ & $\begin{array}{l}\text { Dapat mengubah data } \\
\text { Kartu Keluarga }\end{array}$ & Sesuai \\
\hline & & $\begin{array}{l}\text { Menghapus } \\
\text { data Kartu } \\
\text { Keluarga }\end{array}$ & $\begin{array}{l}\text { Dapat menghapus data } \\
\text { Kartu Keluarga }\end{array}$ & Sesuai \\
\hline & & $\begin{array}{l}\text { Mencari data } \\
\text { Kartu } \\
\text { Keluarga }\end{array}$ & $\begin{array}{l}\text { Dapat menampilkan Kartu } \\
\text { Keluarga }\end{array}$ & Sesuai \\
\hline & $\begin{array}{l}\text { Mengelola } \\
\text { Surat } \\
\text { Pengantar }\end{array}$ & $\begin{array}{l}\text { Melihat data } \\
\text { Surat } \\
\text { Pengantar }\end{array}$ & $\begin{array}{l}\text { Dapat melihat data Surat } \\
\text { Pengantar }\end{array}$ & Sesuai \\
\hline & & $\begin{array}{l}\text { Mengunduh } \\
\text { data Surat } \\
\text { Pengantar }\end{array}$ & $\begin{array}{l}\text { Dapat mengunduh data } \\
\text { Surat Pengantar }\end{array}$ & Sesuai \\
\hline
\end{tabular}




\begin{tabular}{|c|c|c|c|c|}
\hline Aktor & Aktivitas & Kelas Uji & Hasil yang diharapkan & Kesimpulan \\
\hline \multirow[t]{14}{*}{ Penduduk } & \multirow{5}{*}{$\begin{array}{l}\text { Mengajukan } \\
\text { Surat } \\
\text { Pengantar }\end{array}$} & $\begin{array}{l}\text { Melihat data } \\
\text { penganjuan }\end{array}$ & $\begin{array}{l}\text { Dapat melihat data } \\
\text { pengajuan }\end{array}$ & Sesuai \\
\hline & & $\begin{array}{l}\text { Menambah } \\
\text { data } \\
\text { pengajuan }\end{array}$ & $\begin{array}{l}\text { Dapat menambahkan data } \\
\text { pengajuan }\end{array}$ & Sesuai \\
\hline & & $\begin{array}{l}\text { Mengubah } \\
\text { data } \\
\text { pengajuan }\end{array}$ & $\begin{array}{l}\text { Dapat mengubah data } \\
\text { pengajuan }\end{array}$ & Sesuai \\
\hline & & $\begin{array}{l}\text { Menghapus } \\
\text { data } \\
\text { pengajuan }\end{array}$ & $\begin{array}{l}\text { Dapat menghapus data } \\
\text { pengajuan }\end{array}$ & Sesuai \\
\hline & & $\begin{array}{l}\text { Mencari data } \\
\text { pengajuan }\end{array}$ & $\begin{array}{l}\text { Dapat menampilkan data } \\
\text { pengajuan } \\
\text { pencarian }\end{array}$ & Sesuai \\
\hline & \multirow[t]{5}{*}{$\begin{array}{l}\text { Mengisi } \\
\text { Data KK }\end{array}$} & $\begin{array}{l}\text { Melihat data } \\
\text { KK }\end{array}$ & Dapat melihat data $\mathrm{KK}$ & Sesuai \\
\hline & & $\begin{array}{l}\text { Menambah } \\
\text { data anggota } \\
\text { KK }\end{array}$ & $\begin{array}{l}\text { Dapat menambahkan data } \\
\text { anggota KK }\end{array}$ & Sesuai \\
\hline & & $\begin{array}{l}\text { Mengubah } \\
\text { data anggota } \\
\text { KK }\end{array}$ & $\begin{array}{l}\text { Dapat mengubah data } \\
\text { anggota KK }\end{array}$ & Sesuai \\
\hline & & $\begin{array}{l}\text { Menghapus } \\
\text { data anggota } \\
\text { KK }\end{array}$ & $\begin{array}{l}\text { Dapat menghapus data } \\
\text { pengajuan }\end{array}$ & Sesuai \\
\hline & & $\begin{array}{l}\text { Mencari data } \\
\text { anggota KK }\end{array}$ & $\begin{array}{l}\text { Dapat menampilkan data } \\
\text { anggota KK sesuai } \\
\text { pencarian }\end{array}$ & Sesuai \\
\hline & \multirow[t]{4}{*}{$\begin{array}{l}\text { Mengisi } \\
\text { Data KTP }\end{array}$} & $\begin{array}{l}\text { Melihat data } \\
\text { KTP }\end{array}$ & Dapat melihat data KTP & Sesuai \\
\hline & & $\begin{array}{l}\text { Menambah } \\
\text { data KTP }\end{array}$ & Dapat menambahkan KTP & Sesuai \\
\hline & & $\begin{array}{l}\text { Mengubah } \\
\text { data KTP }\end{array}$ & $\begin{array}{lll}\text { Dapat mengubah data } \\
\text { KTP }\end{array}$ & Sesuai \\
\hline & & $\begin{array}{l}\text { Menghapus } \\
\text { data anggota } \\
\text { KK }\end{array}$ & $\begin{array}{l}\text { Dapat menghapus data } \\
\text { KTP }\end{array}$ & Sesuai \\
\hline
\end{tabular}

\section{B. Pembahasan Hasil}

Hasil penelitian adalah perancangan sistem informasi kependudukan di lingkungan RT/ RW berbasis web yang telah diuji menggunakan teknik black box testing. Sistem informasi ini bisa diakses oleh admin, RT/ RW, serta penduduk, sistem informasi tersebut sudah diuji dan berjalan sesuai sebagaimana fungsi yang ada dalam sistem tersebut. Sistem informasi ini telah sesuai untuk menjawab pertanyaan dan masalah penelitian untuk membuat sistem informasi yang bisa mengelola data penduduk, data kartu keluarga, pengajuan surat pengantar serta laporan kependudukan berdasarkan kategori. Sistem informasi ini memiliki peran untuk membantu penduduk dalam pengajuan surat pengantar serta RT/ RW dalam melakukan pengelolaan data penduduk serta pelaporan. 


\section{KESIMPULAN}

Berdasarkan hasil dari pembahasan maka dapat diambil kesimpulan perancangan sistem informasi kependudukan ini berbasis web dibuat menggunakan bahasa pemograman PHP dengan framework Laravel. Sistem informasi kependudukan ini dapat diakses oleh empat pengguna yaitu admin, RT/ RW dan penduduk. Sistem informasi ini memudahkan penduduk dalam membuat pengajuan surat pengantar \& meningkatkan kinerja RT/ RW dalam mengelola data kependudukan serta pelaporan data penduduk. Sistem informasi ini dapat mengelola data KK (Kartu Keluarga) dan KTP (Kartu Tanda Penduduk) dengan hasil akhir berupa laporan yang bisa di cetak berdasarkan kelompok usia, jenis kelamin, agama dan jenjang pendidikaan. Pada sistem informasi ini belum terdapat fitur data pindah datang \& keluar, kelahiran serta kematian serta masih berbasis web. Maka untuk penelitian selanjutnya bisa dilengkapi fitur data pindah datang \& keluar serta mengembangkan sistem menjadi berbasis Android untuk user penduduk.

\section{DAFTAR PUSTAKA}

[1] D. Setiawan, "Dampak Perkembangan Teknologi Informasi dan Komunikasi Terhadap Budaya," $J$. Simbolika Res. Learn. Commun. Study, vol. 4, no. 1, pp. 62-72, 2018, doi: 10.31289/simbollika.v4i1.1474.

[2] E. Amalia and Y. Supriatna, "Perancangan Sistem Informasi Administrasi Kependudukan Sebagai Pengembangan Egoverment," Pros. Semin. Ilmu Komput. dan Teknol. Inf., vol. 2, no. 1, pp. 1-5, 2017.

[3] Rianto, H. Mubarok, and Aradea, "Pelatihan Penerapan Sistem Layanan Administrasi Penduduk Desa Berbasis Teknologi Informasi," J. Pengabdi. Siliwangi, vol. 5, no. 1, pp. 68-72, 2019.

[4] M. Agnitia Lestari, M. Tabrani, and S. Ayumida, "Sistem Informasi Pengolahan Data Administrasi Kependudukan Pada Kantor Desa Pucung Karawang," J. Interkom J. Publ. Ilm. Bid. Teknol. Inf. dan Komun., vol. 13, no. 3, pp. 14-21, 2018, doi: 10.35969/interkom.v13i3.50.

[5] E. Widianto and D. Kurniadi, "Rancang bangun Sistem Informasi Manajemen Keuangan RT/RW Berbasis Web,” J. Algoritm., vol. 18, no. 1, pp. 246-253, 2021, doi: 10.51170/jii.v5i2.92.

[6] W. D. Septiani, "Sistem Informasi Pengelolaan Data Penduduk (Studi Kasus: RT/RW Kelurahan Pondok Kacang Timur)," J. Ilmu Pengetah. Dan Teknol. Komput., vol. 4, no. 1, pp. 23-28, 2018.

[7] S. Hasan, A. T. Hapsari, and A. Mufti, "Sistem Pelayanan Kependudukan RT 002 RW 012 Lubang Buaya," J. Ris. dan Apl. Mhs. Inform., vol. 2, no. 01, pp. 142-148, 2021, doi: 10.30998/jrami.v2i01.504.

[8] S. D. Waluyo and D. Tresnawati, "Pengembangan Sistem Informasi Administrasi Kependudukan di Kantor Kelurahan Berbasis Multimedia,” J. Algoritm., vol. 14, no. 1, pp. 1-6, 2017, doi: 10.33364/algoritma/v.14-1.1.

[9] A. Sabawanti and Bunyamin, "Pengembangan Aplikasi Sistem Informasi Register Kependudukan Pada Bagian Pindah Datang Penduduk di Kelurahan Lebakjaya," J. Algoritm., vol. 11, no. 2, pp. 364-372, 2015, doi: 10.33364/algoritma/v.12-2.364.

[10] N. Syabandhi and A. Mulyani, "Pengembangan Aplikasi Pelayanan Administrasi Kependudukan di Kantor Kelurahan Pataruman Kabupaten Garut," J. Algoritm., vol. 13, no. 1, pp. 70-77, 2016, doi: 10.33364/algoritma/v.13-1.70.

[11] V. Y. P. Ardhana, "Website Based Village Population Data Information System Sistem Informasi Data Kependudukan Desa Berbasis Web," SainsTech Innov. J., vol. 2, no. 2, pp. 1-5, 2019.

[12] Hermanto and Novitasari, "Rancang Bangun Sistem Informasi Kependudukan Desa Parakanlima Berbasis Web Dengan Menggunakan Metode Waterfall," Riser Tek. Inform. dan Komput., vol. 1, no. 2, pp. 1-8, 2019.

[13] P. Kruchten, The Rational Unified Process An Introduction, Second Edition. 2000.

[14] M. A. Ramdhani, D. S. adillah Maylawati, A. S. Amin, and H. Aulawi, "Requirements elicitation in Software Engineering," Int. J. Eng. Technol., vol. 7, no. 2.29 Special Issue 29, pp. 772-775, 2018, doi: 10.14419/ijet.v7i2.29.14254.

[15] Sulistiyani, Endang, Tyas, and S. Hidayatul Yulianing, "Identifikasi Karakteristik Teknik Elisitasi pada Rekayasa Kebutuhan Perangkat Lunak Sebuah Review Sistematis," Inspirasi Prof. Sist. Inf., vol. 8, no. 3, pp. 141-157, 2019. 